\title{
Comparison of the Hemagglutination of Formalinized American Channel Catfish (Ictalurus punctatus) Erythrocytes Between Formalinized and Live Aeromonas hydrophila Isolated from the Catfish Rearing in Kasumigaura Lake in Japan
}

\author{
Kazi Md. AZIMUDDIN ${ }^{1)}$, Kazuhiro HAYAKAWA ${ }^{1)}$, Takuya KANAZAWA ${ }^{1)}$ and Yoshikazu ADACHI ${ }^{1) *}$ \\ 1) Animal Health Laboratory, School of Agriculture, Ibaraki University, 3-21-1 Ami, Ibaraki 300-0393, Japan
}

(Received 5 June 2007/Accepted 12 September 2007)

ABSTRACT. Formalinized Aeromonas (A.) hydrophila agglutinated loosely with the formalinized American channel catfish erythrocytes (FACCE), while live $A$. hydrophila agglutinated tightly with the FACCE. There was a significant difference on the number of attaching bacterial cells to the FACCE $(p<0.01)(\mathrm{n}=40$ erythrocytes) between formalinized and live A. hydrophila. The other bacteria such as Salmonella (S.) Typhimurium ST-5, Escherichia (E.) coli V-517 and Staphylococcus (S.) hyicus ATCC1249 used in this experiment did not attach the FACCE.

KEY WORDS: Aeromonas hydrophila, formalinized American channel catfish erythrocytes, hemagglutination.

A. hydrophila is a causal agent of epizootic ulcerative syndrome disease of catfish [5-8, 11-13]. Kozaki et al. [8] succeeded in purifying a hemolysin from $A$. hydrophila [9], and American channel catfish erythrocytes can be hydrolyzed by the hemolysin as shown in our previous report [2]. Both fish erythrocytes with nucleus and sheep erythrocytes without nucleus were affected by the hemolysin [3-6, 10, 13]. However, hemagglutination of catfish erythrocytes with $A$. hydrophila has never been reported until now.

For this experiment, 8 out of 48 isolates $\left(\mathrm{Ah}_{2}-\mathrm{Ah}_{70}\right)$ of $A$. hydrophila from American channel catfishes rearing in Kasumigaura Lake in Japan have been used. The isolates were identified by Api 20E (biomérieux, France). American channel catfishes have been kindly supplied by The Ibaraki Prefectural Institute of Fresh Water Fish. The bloods were taken from vain of the lateral line by heparinized syringes and kept in the Alsever's solution before use.

For hemagglutination test, American channel catfish erythrocytes (ACCE) were prepared as previously described [2]. A. hydrophila were grown in $15 \mathrm{~m} l$ of Trypticase soy broth (BBL, U.S.A.) for $18 \mathrm{hr}$ at $37^{\circ} \mathrm{C}$. One $\mathrm{ml}$ of the culture was taken and washed three times with saline by the centrifugation at $5,000 \times \mathrm{g}$ for $5 \mathrm{~min}$ at $5^{\circ} \mathrm{C}$. The precipitate was resuspended in $0.5 \mathrm{~m} l$ saline, mixed with equal volume of saline containing $1 \%$ formalin and then, left for $3 \mathrm{hr}$ at room temperature. Formalinized American channel catfish erythrocytes (FACCE) were prepared by the centrifugation of ACCE at $450 \times \mathrm{g}$ for $20 \mathrm{~min}$ at room temperature and the precipitate were mixed with $9 \mathrm{~m} l$ of saline containing $10 \%$ formalin and left for $4 \mathrm{hr}$ at room temperature. The FACCE were washed 3 times with saline by the centrifugation at 450 $\times \mathrm{g}$ for $20 \mathrm{~min}$ at room temperature. Before the hemagglutination test, the bacterial cell number in the suspension was adjusted at McFarland standard No. 1. Two hundred and

\footnotetext{
* Correspondence to: AdAchi, Y., School of Agriculture, Ibaraki University, 3-21-1 Ami, Ibaraki 300-0393, Japan.

e-mail: adachi@mx.ibaraki.ac.jp
}

fifty $\mu l$ of the suspension was taken and mixed with equal volume of FACCE in the test. Salmonella (S.) Typhimurium ST-5, Escherichia (E.) coli V-517 and Staphylococcus (S.) hyicus ATCC1249 were also used for the comparison of the hemagglutination with $A$. hydrophila. The mixtures were left at each of $5,10,20,30$ and $37^{\circ} \mathrm{C}$ for $12 \mathrm{hr}$ and then, the reaction was observed under a phase contrast microscope (Olympus, Japan). The number of the attaching bacteria per 40 FACCEs was counted and the number of the attaching bacteria per one FACCE was shown as the mean \pm standard deviation (SD).

The hemagglutination (adherent bacterial cells/one FACCE) between live and formalinized $A$ hydrophila was statistically treated with $t$-test (Microsoft Excel software).

Eight Aeromonas isolates which were selected on the basis of the preliminary experiment results concerning the hemagglutination, agglutinated well with FACCE (Table 1). Among the five different temperatures, best hemagglutination condition was at $10^{\circ} \mathrm{C}$ for $6 \mathrm{hr}$ (Fig. 1). The isolates $\mathrm{Ah}_{25}, \mathrm{Ah}_{27}, \mathrm{Ah}_{28}$ and $\mathrm{Ah}_{70}$ attached well with $\mathrm{FACCE}$ and the selected number of attaching bacterial cells per one FACCE were $2.99 \pm 0.21$ (mean \pm SD) ( $n=40$ erythrocytes), $2.97 \pm 0.14,3.19 \pm 0.18$ and $3.11 \pm 0.11$ respectively, while the number of bacterial cells in the isolates $\mathrm{Ah}_{2}, \mathrm{Ah}_{3}, \mathrm{Ah}_{4}$ and $\mathrm{Ah}_{8}$ were $2.65 \pm 0.19,2.53 \pm 0.13,2.69 \pm 0.16$ and 2.74 \pm 0.22 , respectively (Table 1 , Fig. 1). However, there was no significant difference $(\mathrm{p}<0.01)$ among the isolates on the hemagglutination with FACCE (Table 1). Microscopic observation results demonstrated that live Aeromonas cells agglutinated well with FACCE (Fig. 3L) while formalinized Aeromonas cells agglutinate loosely with the FACCE (Fig. $3 \mathrm{~F}$ ). Amongst the Aeromonas isolates, both live and formalinized $\mathrm{Ah}_{28}$ attached well to FACCE and the numbers of the attaching bacterial cells per FACCE were $3.19 \pm 0.18$ in case of live bacteria and $2.02 \pm 0.18$ in case of formalinized bacteria, respectively (Table 1). There was a significant difference $(p<0.01)$ between live and formalinized bacterial 
Table 1. Comparison of the hemagglutination between formalinized and live bacteria with FACCE

\begin{tabular}{ccc}
\hline Isolates & $\begin{array}{c}\text { Adherent of formalinized } \\
\text { bacteria/one FACCE }\end{array}$ & $\begin{array}{c}\text { Adherent of live } \\
\text { bacteria/one FACCE }\end{array}$ \\
\hline $\begin{array}{c}\text { Aeromonas. hydrophila } \\
\mathrm{Ah}_{2}\end{array}$ & $1.64 \pm 0.12^{\mathrm{c})}$ & $2.65 \pm 0.19^{\mathrm{d})}$ \\
$\mathrm{Ah}_{3}$ & $1.66 \pm 0.17$ & $2.53 \pm 0.13$ \\
$\mathrm{Ah}_{4}$ & $1.72 \pm 0.22$ & $2.69 \pm 0.16$ \\
$\mathrm{Ah}_{8}$ & $1.69 \pm 0.19$ & $2.74 \pm 0.22$ \\
$\mathrm{Ah}_{25}$ & $1.78 \pm 0.16$ & $2.99 \pm 0.21$ \\
$\mathrm{Ah}_{27}$ & $1.86 \pm 0.21$ & $2.97 \pm 0.14$ \\
$\mathrm{Ah}_{28}$ & $2.02 \pm 0.18$ & $3.19 \pm 0.18$ \\
$\mathrm{Ah}$ & $2.07 \pm 0.15$ & $3.11 \pm 0.11$ \\
Salmonella. Typhimuriunm & $0.00 \pm 0.00$ & $0.00 \pm 0.00$ \\
$\mathrm{ST}-5$ & $0.00 \pm 0.00$ & $0.00 \pm 0.00$ \\
Escherichia. coli & & \\
V-517 & $0.00 \pm 0.00$ & $0.00 \pm 0.00$ \\
Staphylococcus. hyicus & & \\
ATCC1249 &
\end{tabular}

a) Not significantly different among the isolates; b) Not significantly different among the isolates; c) Adherent bacterial cells/one FACCE; d) The value was expressed as mean $\pm \mathrm{SD}(\mathrm{n}=40$ erythrocytes). There was significant difference between a and $\mathrm{b}$ by $t$ test $(p<0.01)$.

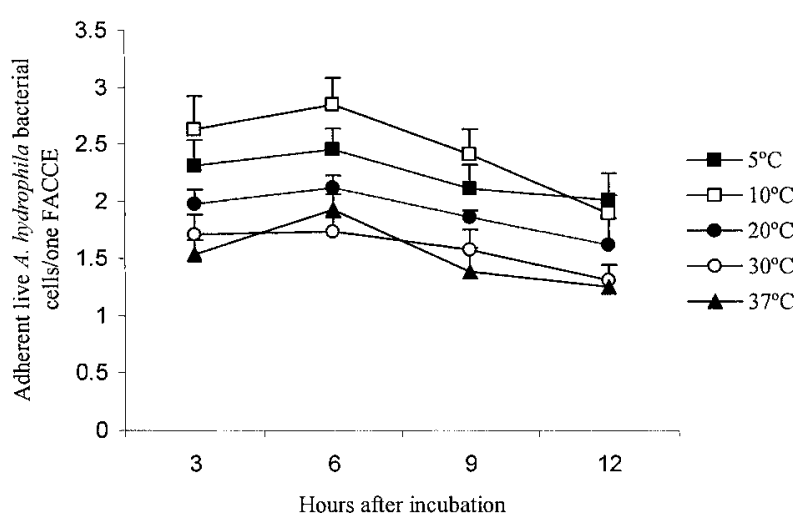

Fig. 1. Comparison the hemagglutination (adherent A. hydrophila bacterial cells/ one FACCE) of live $A$. hydrophila isolates in FACCE in different temperatures and different time intervals. The number of the attached $A$. hydrophila per FACCE was shown as mean $\pm \mathrm{SD}$ ( $\mathrm{n}=40$ erythrocytes). The vertical bar indicates standard deviation value mentioned above.

cells as shown in Fig. 2 in point of the attaching bacteria number to FACCE. In contrast, $S$. Typhimurium ST-5, $E$. coli $\mathrm{V}-517$, and $S$. hyicus ATCC1249 were used for contradiction to non-specific hemagglutination with Aeromonas isolates and they never attached the FACCE (Fig. 3L \& 3F). American channel catfish erythrocytes have been used in this experiment because the catfishes were real host to the isolates. In addition, the formalinized erythrocytes have been used for the observation of the real hemagglutination because non-formalinized erythrocytes were broken quickly by the hemolysin. On the other hand, in case of chick erythrocytes, the hemagglutination with Aeromonas isolates have been observed but it was week, compared with those of the

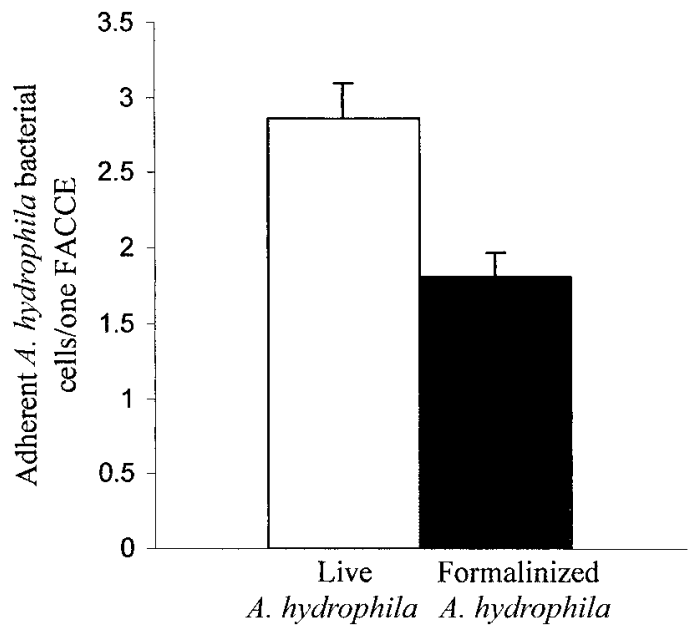

Fig. 2. Comparison of the hemagglutination (adherent $A$. hydrophila bacterial cells/ one FACCE) of live and formalinized $A$. hydrophila isolate in FACCE. The number of the attached $A$. hydrophila per FACCE was shown as mean \pm $\mathrm{SD}$ ( $\mathrm{n}=40$ erythrocytes). The vertical bar indicates standard deviation value mentioned above. There was a significant difference in point of the attaching bacteria per one FACCE, between formalinized and live $A$. hydrophila by $t$ test $(p<0.01)$.

American channel catfish erythrocytes (unpublished data).

In the hemagglutination contributing the human isolates of $A$. hydrophila, human erythrocytes has been used [1]. In our experiment, $A$. hydrophila from American channel catfish has been used for the analysis of the agglutination with American channel catfish erythrocytes. This is the first experiment using American channel catfish erythrocytes. Hemagglutination between Aeromonas cells and FACCE is 
$\mathbf{L}$

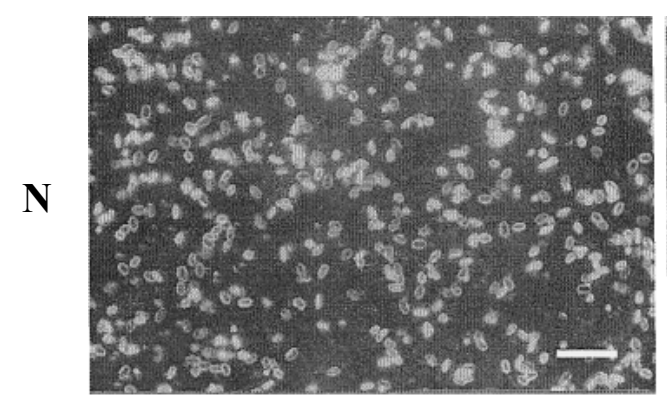

$\mathrm{Ah}_{28}$

EC
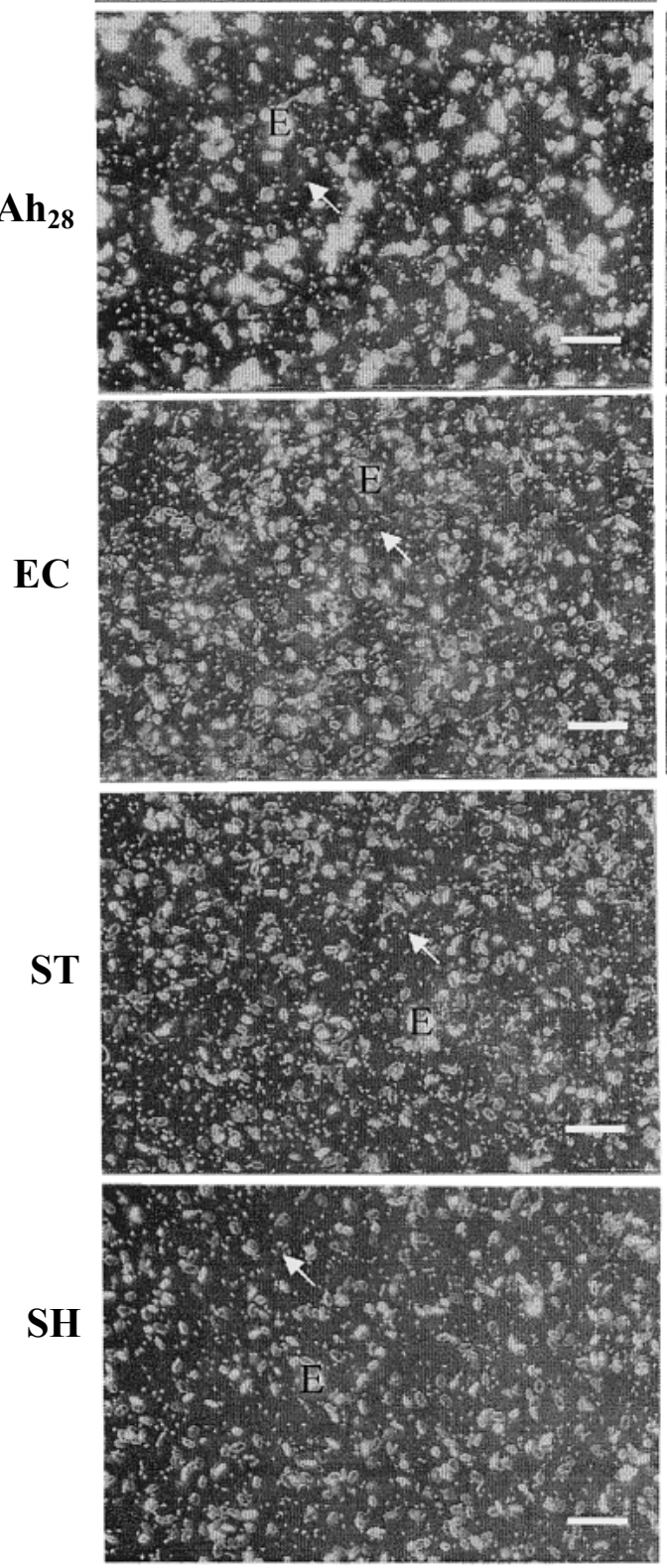

$\mathbf{F}$
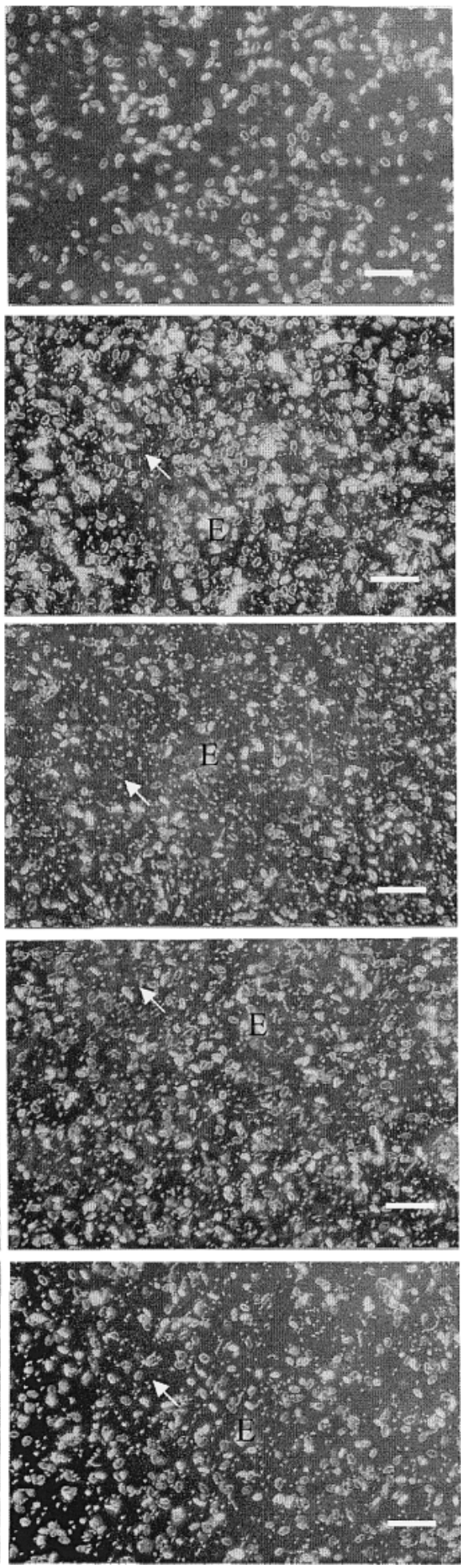

Fig. 3. Hemagglutination with (L) live, (F) formalinized bacteria in FACCE. Ah, A.hydrophila; EC, E. coli V-517; ST, S. Typhimurium ST-5; SH, S. hycus ATCC1249; N, negative control without bacteria; E, erythrocyte. Arrows show the bacteria. $\mathrm{Bar}=20 \mu \mathrm{m}$. 
very important for the investigation of the adhesions concerning the virulence factors. Furthermore, FACCE still kept receptor activity. Therefore, we thought it may consist of a kind of glycoprotein. Hemolysin is also one of the virulence factors of $A$. hydrophila. In our previous experiment on Aeromonas hemolysin, we found $\mathrm{Ah}_{25}, \mathrm{Ah}_{27}, \mathrm{Ah}_{28}$ and $\mathrm{Ah}_{70}$ showed strong hemolysis on agar containing ACCE, while the isolates $\mathrm{Ah}_{2}, \mathrm{Ah}_{3}, \mathrm{Ah}_{4}$ and $\mathrm{Ah}_{8}$ showed weak hemolysis [2]. This result may indicate the good correlation between hemagglutination and hemolysis. This means strong hemolytic and hemagglutination isolates may be high virulent $A$. hydrophila. We will attempt to investigate electronmicroscopically the adhesion of Aeromonas to the receptor of catfish erythrocyte and will clarify the adhesin and the receptor biochemically concerning the hemagglutination.

\section{REFERENCES}

1. Atkinson, H.M. and Trust, T.J. 1984. Infect. Immun. 27: 938 946.
2. Azimuddin, M.K. and Adachi, Y. 2005. Jpn. J. Anim. Hyg. 31: $11-14$.

3. Buckely, J.T. and Howard, S.P. 1988. Methods. Enzymol. 169: 2869-71.

4. Hirano, I. and Aoki, T. 1991. Microb. Pathog. 11: 189-197.

5. Howard, S.P., Garland, W.J, GreeM, J. N. and Bukley, J.T. 1987. J. Bacteriol. 69: 2869-2871.

6. Ishigura, E.E. and Trust, T.J. 1981. Dev. Biol. Stand. 49: 163168.

7. Janda, J.M. and Duffy P.C.1988. Rev. Infect. Dis. 10: 980-997.

8. Kozaki, S.A., Tsutomu, Yoichk, I. and Sakaguchg, I. 1989. J. Clin. Microbiol. 27:1782-1786.

9. Monfort, P. and Baluex, B. 1990. Appl. Env. Microbiol. 56: 1999-2006.

10. Rahman, M., Colique- Navarro, P., Kuhn, I., Huys, G., Swing, J. and Mollby, R. 2001. Appl. Env. Micoibiol. 62: 650-655.

11. Sadruddin, F.H., Jiwa. 1983. Vet. Microb. 8: 17-34.

12. Santos, J.A., Gonzalez, J.C., Otero, A. and Lopez, G.L.M. 1999. J. App and Env. Microbiol. 65: 5612-5614.

13. Thune, R.I., Stanley, L.A. and Cooper, R.K. 1993. Fish Annu. Rev.Fish Dis. 3: 37-68. 